\title{
HIDUP DI DUNIA MULTIKULTURAL \\ POTRET SOSIAL BUDAYA KERUKUNAN ETNIS MINANG DAN TIONGHOA DI KOTA PADANG
}

\author{
Rahmi Surya Dewi \\ Jurusan Ilmu Komunikasi Fisip Universitas Andalas Padang \\ Email: rahmi.ikom@gmail.com
}

ARTICLE INFO
ABSTRACT
$\begin{aligned} & \text { The issue of indigenous and non-indigenous, minorities and the majority has } \\ & \text { become an exaggerated issue causing the sentiment and the disturbance of } \\ & \text { relations between ethnic minorities and ethnic majority. This article was } \\ & \text { intentionally written to see a portrait of harmony between ethnic Minang and } \\ & \text { Tionghoa in Padang City. Lately it is so easy to insult and degrade the religion of } \\ & \text { others. Therefore, this article aims to provide awareness to the parties who } \\ & \text { deliberately divide relations and harmony among tribes, religions, races and } \\ & \text { groups in Indonesia. One of portraits of inter-ethnic and inter-religious harmony } \\ & \text { Can be seen in West Sumatra. The ability of ethnic Chinese to be ethnic Minang } \\ & \text { Culture, } \\ & \text { harmony, } \\ & \text { ethnic Chinese, } \\ & \text { ethnic Minang. }\end{aligned} \quad \begin{aligned} & \text { potential of conflict can be minimized. The harmony between the two ethnics could } \\ & \text { frequently end with inter-ethnic marriage. }\end{aligned}$

\section{Pendahuluan}

Akhir-akhir ini isu pribumi dan non pribumi, isu masyarakat minoritas dan mayoritas telah menjadi sebuah isu yang dibesar-besarkan oleh segelintir orang. Isu tersebut berkembang menjadi perilaku saling merendahkan, menghina bahkan memperlebar jurang pemisah antara etnis yang secara kuantitatif berjumlah kecil (minoritas) namun bisa saja secara sosial ekonomi lebih menguasai (mayoritas) dengan etnis yang berjumlah besar (mayoritas) tapi bisa saja dari sisi kebijakan sosial ekonomi dan sosial politik justru minoritas. Kerukunan antar umat beragama sudah terganggu disebabkan pelecehan oleh oknum tertentu sehingga dapat mengancam persatuan dan kesatuan bangsa. Tulisan ini hadir untuk memotret kerukunan antar etnis yang ada di Sumatera Barat, khususnya etnis Tionghoa dan etnis Minang.

Kota Padang yang merupakan ibu kota Provinsi Sumatera Barat ada beberapa etnik di luar etnik Minang yang berdomisili bahkan telah berkembang keturunannya di kota Padang. Di antara etnik-etnik tersebut adalah etnik Jawa, Melayu, Tionghoa, Nias, Mentawai, Batak, Aceh, Tamil dan lainnya (Erniwati, 2007:38; BPS Kota Padang). Namun dalam paper ini penulis lebih memfokuskan pada etnik Tionghoa, karena etnik Tionghoa ini cukup besar jumlahnya dibanding etnik lainnya di luar etnik Minang (sebagai masyarakat asli pribumi).

Tujuan penulisan artikel ini untuk menggambarkan kondisi sosial etnis Tionghoa dari segi kehidupan sosial di bidang ekonomi, pemerintahan dan komunikasi budaya dengan penduduk pribumi (suku Minang) di kota Padang Sumatera Barat. Selain itu, artikel ini diharapakan dapat memberikan penyadaran akan pentingnya saling menghormati dan menghargai antar etnis serta antar pemeluk agama. Penelitian tentang ini telah banyak dilakukan oleh peneliti sebelumnya mulai dari tingkat skripsi sampai kepada tingkat disertasi mahasiswa doktoral. Beberapa hasil penelitian tersebut penulis kutip sebagai bahan referensi. Penulis pun mengadakan mini riset berupa studi literatur serta wawancara dengan beberapa orang untuk memperkuat dan memberikan gambaran yang lebih komprehensif terkait artikel ini.

Bila diamati secara umum, perbedaan etnik Tionghoa dan Minang, ada pada sistem sosial, patrilineal (Tionghoa) dan matrilineal (Minang) serta perbedaan Agama atau keyakinan. Persamaannya lebih banyak dari segi etos pedagang yang juga berpengaruh pada kesamaan lain yang bersifat situasional (Makmur, 2018). Mata pencarian etnis Tionghoa di Padang mayoritas bergerak di 
bidang perdagangan. Perdagangan yang mereka lakukan lebih banyak berdagang grosiran, walau ada beberapa yang bersifat eceran. Namun, ada hal yang berbeda jika diamati tempat berdagang mereka. Mereka pada umumnya berdagang di wilayah tempat kediaman mereka, yang oleh masyarakat setempat menyebutnya dengan daerah "pondok" atau "kampung pondok". Dengan kekhasan tokonya, rata-rata bertingkat yang sering disebut ruko. Komoditi yang mereka jual adalah barang-barang elektronik, outomotif, makanan dan fashion. Para pedagang etnis Tionghoa di Padang, terlihat lebih terpusat pada satu perkampungan mereka tersebut, hampir tidak terlihat mereka berdagang yang berbaur (kalau pun ada, satu atau dua, tetapi mereka bergerak di (belakang layar) dengan mengambil pegawai dari etnis Minang.

Hal ini terlihat berbeda bila dibandingkan dengan etnis Tionghoa di Bukittinggi dan Batusangkar, di mana mereka lebih meyebar dan berbaur dengan masyarakat setempat. Hal yang menarik dari Tionghoa di kota Padang adalah walau "lokalisasi" tempat tinggal dan tempat berdagang mereka, tetapi dari sisi perdagangan mereka cukup kuat. Persaingan perdagangan mereka dengan etnis Minang sebagai (masyarakat pribumi) lebih pada segi kualitas dan harga, bahkan tidak jarang para pedagang Minang pun membeli dagangan mereka untuk dijual kembali.

Akhir-akhir ini jumlah dan perkembangan etnis Tionghoa di Padang agak menurun dibandingkan pada tahun 1990-an. Menurut pengamatan dan wawancara penulis dengan beberapa orang dari etnis Tionghoa, secara umum penurunan tersebut disebabkan oleh dua hal, yaitu terjadinya perpindahan beberapa kepala keluarga atau anak cucu mereka sejak kejadian kerusuhan pada tahun 1998 saat krisis moneter melanda Indonesia, ditambah lagi peristiwa bencana alam gempa pada tahun 2009, yang menyebabkan perpindahan mereka semakin meningkat. Selain itu, mereka mengembangkan bisnis dan perdagangan di daerah lain. Adapun daerah yang dituju lebih banyak adalah daerah Pekanbaru Riau, Medan dan Jambi. Di daerah-daerah tersebut perdagangan mereka lebih maju dibandingkan dengan kota Padang. Hal ini juga terjadi pada Etnis Tionghoa di Bukittinggi, sebagaimana hasil penelitian berikut; yang berjudul dimensi sosial etnis Tionghoa yang bermukim di Kota Bukittinggi menunjukkan bahwa: jumlah etnis Tionghoa di Bukittinggi pada tahun 2012 mengalami penurunan ( \pm 500 orang). Penurunan jumlah etnis Tionghoa di Kota Bukittinggi disebabkan oleh faktor mobilitas dan migrasi (Novalita, 2013). Jika di Bukittinggi penurunan jumlah etnis Tionghoa lebih disebabkan oleh mobilitas dan migrasi, sementara di kota Padang lebih terlihat karena faktor kondisi alam yang rawan gempa.

Pemungkiman etnis Tionghoa di Bukittingi juga berbeda dengan di kota Padang, jika di Padang mereka cenderung pada satu pemungkinan yang disebut "kampung pondok", tapi di Bukittingi Mayoritas pemukiman etnis Tionghoa sudah menyebar di beberapa tempat seperti: Kecematan Guguk Panjang, Kelurahan Benteng Pasar Atas, sedangkan etnis Tionghoa yang lain menyebar di tempat lain, seperti Tembok Bawah, Jenjang Empat Puluh, dan Pasar Bawah yang termasuk Kelurahan Aur Tajungkang. Mayoritas etnis Tionghoa bergerak di bidang perdagangan, karena itu pulalah mungkin mereka menyebar menempati lokasi strategis untuk berdagang di kota Bukittinggi.

Di Padang Sumatera Barat, perdagangan dan perekonomian dari segi tempat lebih di dominasi oleh etnis Minang, hal ini sangat berbeda bila dibandingkan dengan daerah lain, salah satu contohnya daerah Pontianak. Di Pontianak perdagangan dan perekonomian didominasi oleh etnik Cina (Tionghoa) seperti yang dilansir harian Kompas (3/2/2011) di Kota Pontianak, Provinsi Kalimantan Barat, di dua kawasan pecinaan, yakni Jalan Gajah Mada dan Tanjungpura, yang merupakan urat nadi perekonomian di Kota Pontianak, pada saat perayaan imlek mereka tutup karena sebagian besar pemilik toko warga Tionghoa merayakan Tahun Baru Imlek (https://ikifuturity.wordpress.com). Adapun kegiatan perdagangan dan perilaku ekonomi Tiongha cenderung bersifat proaktif, usaha atau perusahaan yang dikelola biasanya berbentuk usaha keluarga, hal ini sudah menjadi ciri etnis Tionghoa di kawasan Asia termasuk Indonesia. Dalam hal ini, etnis Tionghoa mengandalkan integritas suatu hubungan antar mereka di bidang ekonomi dan kekeluargaan. Sedangkan bentuk kolaborasi perilaku etnis Cina di Indonesia terutama kelas menengah dan kelas atas, bersifat tidak terikat secara profesi.

\section{Kerukunan antara Etnis Tionghoa dengan Etnis Minang}

Di daerah Sumatera Barat, masyarakat tidak terlalu ikut campur (kurang perhatiannya) terhadap urusan politik dan pemerintahan, sejauh urusan perdagangan dan bisnis mereka aman, maka 
kerusuhan dan kekacauan tidak terjadi, jika pun demonstrasi terjadi, hal itu diakibatkan oleh kebijakan pemerintah yang berkaitan dengan perdagangan dan bisnis masyarakat.

Jika dilihat dan diamati kerukunan antara etnis Minang dengan etnis Tionghoa atau cina di kota Padang, mereka terlihat hidup rukun. Tidak terlihat gejolak atau kerusuhan antara etnis Tionghoa dengan etnis Minang sebagai penduduk pribumi. Banyak para ilmuan melakukan penelitian terhadap etnis Tionghoa dan etnis Minang di kota Padang. Salah satunya adalah penelitian Erniwati alumni program doktoral Universitas Indonesia, dengan disertasinya berjudul "Cina Padang dalam Dinamika Masyarakat Minangkabau: Dari Revolusi Sampai Reformasi". Menurut Erniwati, Eratnya hubungan antara etnis Minangkabau dengan "Cina Padang" sebagai kekuatan ekonomi dan sosial yang dominan di Kota Padang, mengakibatkan kebijakan represif Orde Baru yang terjadi di seluruh kota di Indonesia tidak begitu dirasakan oleh etnis Cina di Kota Padang. Hal itu disebabkan oleh salah satunya peran Himpunan Tjinta Teman (HTT) berdiri 1861 dan Himpunan Bersatu Teguh (HBT) berdiri 1871 sebagai simbol kekuatan etnis Cina (Tionghoa) di Kota Padang bisa menampilkan diri sebagai simbol keutuhan budaya etnis Cina Padang yang sekaligus menjadi simbol pencitraan asimilasi budaya etnis Cina dan etnis Minangkabau, serta budaya tradisional Cina. "Secara mikro kedua perkumpulan ini menjadi simbol kerjasama harmonis di tingkat lokal, sementara secara makro etnis Cina dan etnis Minangkabau bisa berdampingan dalam kehidupan sosial ekonomi (Erniwati, 2011).

Khusus untuk kajian HBT telah diteliti juga oleh Riniwaty Makmur baru-baru ini, yang berjudul Etnik Tionghoa di Kota Padang (Studi Kasus Mengenai Komunikasi di Dalam Konstruksi Realitas Sosial pada Perkumpulan Etnik Tionghoa Himpunan Bersatu Reguh/HBT di kota Padang. Riniwaty menyatakan bahwa di samping rangkaian kegiatan HBT, orang Tionghoa menerima pengaruh buaya Minang seperti cara bicara dan perilaku komunikatif yang lebih egaliter (tidak berjarak) sehingga orang Tionghoa di Padang telah mengalami hibriditas kebudayaan (Makmur, 2018).

Dalam hal komunikasi di antara mereka, ada hal yang menarik tentang bahasa yang berkembang di kawasan domisili mereka " Kampung Pondok" disebut dengan 'bahasa pondok' atau "bahasa Minang Pondok". Istilah 'bahasa pondok' disebut oleh Erniwati sebagai perbauran antara bahasa Indonesia dengan bahasa Minang, namun memakai logat Mandarin. Hal ini menjadi fenomena unik di kalangan etnis Tionghoa Padang, secara mayoritas di antara mereka sudah tidak bisa berbahasa Cina lagi. Bahasa pondok ini berkembang dalam kehidupan keseharian mereka apalagi jika akan tampak jelas terlihat saat kegiatan perkumpulan sosial mereka dalam acara budaya dan kematian (HTT dan HBT). Adapun ungkapan yang paling banyak digunakan seperti " tuako, koko, jiko, shako, ii, cece" dan lain-lain. "Bahasa Minang Pondok" menjadi benang merah yang menyatukan seluruh konstruksi sosial masyarakat etnik Tionghoa di kota Padang (Makmur, 2018).

Kemampuan adabtasi etnis Tionghoa dan sistem matrilineal yang dianut oleh etnis Minang membuat potensi konflik dapat diredam. Di Padang, konflik atau kerusuhan antar suku nyaris tidak terjadi, salah satu sebabnya adalah di Minang memakai sistem matrilineal yang dikenal dengan Bundo Kanduang menekankan unsur motherhood dalam masyarakat Minang, mencakup nilai-nilai melindungi, kesabaran, kebijaksanaan, dan persuasi, tidak hanya mempengaruhi cara masyarakat Minang membangun relasi dengan etnik lain, tetapi sekaligus membentuk perilaku politik masyarakat Minang dalam merespon kebijakan yang diinisiasi oleh negara, termasuk yang berimplikasi pada relasi antar etnik di Padang (Alfirdaus, 2014).

Kedua etnik ini Minang dan Cina adalah etnik yang kuat dalam berdagang termasuk juga kuat dalam religi, yang seharusnya potensi konflik akan gampang terjadi, namun hal itu tidak berlaku di ranah Minang, etika dagang yang mereka pakai, membuat mereka saling menghormati. Mungkin hal ini, juga disebabkan karena pengalokasian wilayah pemukiman Tionghoa, yaitu "kampung Pondok" yang dijadikan tempat tinggal sekaligus tempat usaha bagi etnis Tionghoa sehingga persaingan dagang dengan etnis Minang (orang pribumi) tidak kentara karena orang pribumi menguasai pasar pusat dan dominan di pusat-pusat perbelanjaan. Namun bukan berarti di pusat perbelanjaan, Cina tidak mengambil peran, beberapa dari etnis Cina yang mapan justru menjadi investor dalam membangun pusat-pusat perbelanjaan tersebut (seperti Supermarket).

Selain etika berdagang yang dipegang kuat oleh etnik Tionghoa, mereka juga menguasai bahasa Minang bahkan lebih dari $90 \%$ dari mereka yang menetap di Sumatera Barat, khususnya kota Padang tidak bisa berbahasa Cina atau mandarin. Hal ini disebabkan mereka merupakan peranakan Cina, yang lahir dan besar di Sumatera Barat, bahkan di antara mereka juga banyak yang menikah 
dengan etnik Minang, rata-rata mereka pindah agama ke agama Islam. Hal ini merupakan faktor yang mempercepat terjadinya akulturasi budaya pada etnik mayoritas.

Ada beberapa hal yang menggembirakan bagi etnis Tionghoa setelah berakhirnya masa orde baru, dan masuk pada era reformasi. Etnis Tionghoa lebih leluasa dalam pertunjukan budayanya, yang dahulu sangat dibatasi. Misalnya dahulu, dilarang kesenian Cina seperti Barongsai untuk dimainkan apalagi ditayangkan lewat media massa, namun sekarang hal itu tidak terjadi lagi. Di Padang, Imlek atau cap Go Meh terlihat lebih meriah dibandingkan dengan masa orde baru. Hal menarik lainnya adalah acara sipasan yang berlangsung sangat meriah. Adapun bukti lain dari terjadinya akulturasi dari segi bahasa yang mereka gunakan, sebagai contoh "Pigi mana lu" (mau kemana kamu), ungkapan : "kecik telok gedang" (air kecil telur besar), nya ndak mau o (ia tidak mau).

Menurut Erniwati, ada perubahan yang dramtis terjadi di kalangan etnis Tionghoa Padang, yaitu munculnya kompetensi intern dalam kelompok-kelompok etnis, marga dan perkumpulan sosial budaya dan kematian. "masing-masing kelompok menampilkan identitas khusus mereka dan bersaing dalam bentuk kompetisi seperti perlombaan budaya, pentas kesenian dan acara-acara serimonial dengan latar belakang sosial dan keagamaan.” (Erniwati, 2011).

\section{Gender dan Komunikasi}

Di Sumatera Barat yang menganut sistem matrilineal atau sistem keturunan menurut garis keturunan ibu, pada prinsipnya sangat menghargai ibu. Dalam mengambil satu keputusan besar maka seorang ibu akan dilibatkan dalam memutuskan suatu perkara. Namun pada masa orde baru, khususnya dalam bidang perpolitikan perempuan kurang mendapat tempat dan kurang dilibatkan karena aturan-aturan yang mengikat saat itu. Menurut Uhlin (1997), struktur hubungan gender dalam perpolitikan di masa orde baru telah turut menyokong otoritarianisme di Indonesia, struktur hubungan gender dalam perpolitikan orde baru dapat ditemui sebagai kebijakan-kebijakan sebagai output dari sistem politik (Uhlin, 1997).

Khusus bagi perempuan etnis Tionghoa yang telah menjadi warga Negara Indonesia (WNI), kondisi diperparah oleh rezim orde baru dengan melakukan politik diskriminasi sehingga kebebasan politik etnis Tionghoa menjadi terbelenggu. Perempuan etnis Tionghoa mengalami double discrimination (diskriminasi ganda). Mereka didiskriminasi bukan saja karena mereka berasal dari etnis minoritas tetapi juga karena mereka perempuan. Marjinalisasi politik yang dialami perempuan etnis Cina ditengarai dalam dua pandangan. Pandangan yang pertama beranggapan bahwa ketidakaktifan etnis Cina (termasuk perempuan) dalam bidang politik adalah bagian dari usaha mereka tidak menonjol dengan harapan dapat tetap mempertahankan posisi mereka di sektor ekonomi. Pendapat lain mengungkapkan bahwa sumber-sumber politik secara formal memang sengaja disumbat oleh penguasa supaya mereka selalu bergantung kepada kekuasaan politik dan ekonomi (Saputra, 2001).

Berdasarkan penelitian yang dilakukan oleh Al Rafni yang dimuat dalam jurnal Demokrasi tahun 2007 (Rafni, 2007) maka dapat diketahui data empiris tentang akses atau keterlibatan perempuan etnis Cina (Tionghoa) dalam pemilu legislatif 2004 di Kota Padang meliputi tiga jenis akses yaitu: Pertama, akses atau keterlibatan dalam memilih (melakukan pemberian suara), dimana semua responden (100\%) menyatakan telah menggunakan hak pilihnya dalam pemilu legislatif tersebut. Kedua, sejumlah $20 \%$ responden juga memberikan pernyataan turut memperjuangkan isu pemberdayaan perempuan. Ketiga, menjadi simpatisan/ penggembira suatu partai dinyatakan oleh sejumlah $16,67 \%$ responden. Sedangkan jenis akses yang lain terlihat sangat rendah sekali, terutama sekali dalam hal-hal yang menuntut kecakapan/skill politik tertentu. Dari hasil penelitian yang dilakukan oleh Rafni sangat jelas tergambar bahwa etnis Tionghoa di Padang sangat rendah keinginan ataupun keterlibatan mereka dalam perpolitikan. Mereka hanya sebatas partisipan yang ikut serta memberikan suara pada saat pesta demokrasi dilakukan. Rendahnya keinginan ini dipertegas oleh kutipan hasil wawancara Rafni, di antaranya sebagai berikut;

Pernyataan salah seorang responden perempuan dari etnis Tionghoa dengan inisial YS yaitu;

"Bagi kami politik itu adalah suatu pembicaraan yang tidak perlu dilakukan di arena umum. Membicarakan kehidupan politik itu harus penuh kehati-hatian. Salah-salah cakap akan mendatangkan bala pada kita." 
"Bagi saya pribadi, ikut dalam kegiatan partai atau aktifitas politik lainnya adalah sesuatu yang sangat sulit, karena waktu dan kesempatan untuk itu tidak ada. Selain mengurusi keluarga, saya juga bekerja/dagang sehingga tidak ada lagi perhatian

Berdasarkan pernyataan tersebut di atas, peneliti menyimpulkan bahwa walau di kota Padang yang penduduknya didominasi oleh warga pribumi yang beretnis Minang, perempuan Tionghoa tidaklah dihambat dalam keterlibatannya ditingkat kepengurusannya dalam sebuah partai, namun mereka sendiri yang tidak berkeinginan untuk "duduk" dalam sektor pemerintahan ataupun terlibat sebagai pengurus partai. Mereka lebih memilih untuk menjadi pedagang ataupun pengusaha. Dalam beberapa hal relasi antara etnis Tionghoa dengan Pemerintah ataupun pihak swasta terjadi dalam hal untuk menanamkan saham dalam suatu proyek besar. Mereka lebih memilih bergerak di belakang layar teurtama dalam sektor bisnis dan ekonomi.

Selain persoalan politik, komunikasi gender di kota Padang sangat terlihat pada suatu kasus, di mana seorang gadis keturunan etnik Tionghoa "tertawan hatinya terhadap pria keturunan etnik Minang" maka dalam hal ini, sangat sulit bagi keluarga etnik Minang (keluarga pria) untuk dapat menerima gadis etnik Tionghoa tersebut untuk diterima menjadi menantu. Walau di Padang tidak terlihat gejolak ataupun konflik bahkan jika dibandingkan dengan daerah lain, etnik Tionghoa di Padang lebih terlihat rukun berdampingan dengan masyarakat pribumi yang beretnik Minang. Namun dalam hal pernikahan sampai saat ini mayoritas dari etnik Minang sangat sulit untuk diterima menjadi menantu di keluarga besar mereka. Hal ini tidak hanya berlaku bagi perempuan saja tetapi juga bagi laki-laki. Jika pun ada satu atau dua kasus, biasanya mereka akan diterima dengan melewati proses di mana keturunan etnis Tionghoa tersebut harus dapat mengikuti ajaran atau agama Islam.

\section{Perspektif Etnis Lain}

Terkait dengan perspektif terhadap etnik Tionghoa dapat terlihat dalam film "jangan panggil aku Cina" dalam film tersebut jelas merepresentasikan kurang senangnya etnik Tionghoa disebut Cina sama halnya kurang senangnya etnik Minang disebut dengan "orang Padang". Jika etnik Tionghoa lebih senang disebut orang "Tionghoa dibandingkan dengan orang Cina maka begitupula halnya dengan etnik Minang yang lebih senang disebut "orang Minang" dibandingkan dengan sebutan orang "Padang". Dalam sejarahnya masing-masing mempunyai cerita tersendiri yang bermuatan negatif baik itu tentang "Cina" ataupun "Padang".

Begitu pula halnya dengan sebutan orang Padang, kebanyakan orang etnik Minang kurang suka disebut orang Padang karena istilah Padang sering dianggap identik dengan pedagang Nasi atau pedagang kaki lima bahkan muatan negatifnya dianggap dilabelkan dengan "padang bengkok", dan "padang pelit" selain juga singkatan dari istilah "pandai berdagang". Hal ini salah satu penyebab orang Padang lebih senang disebut sebagai orang Minang, karena kata Minang lebih bermuatan positif, dianggap sebagai salah satu suku yang besar di Indonesia bahkan diakui atau dihormati di semenanjung Malaka, selain itu kata Minang lebih membawa muatan positif karena falsafahnya yang dikenal dengan "Adat basandi Syarak, Syarak basandi Kitabullah". Artinya adat - istiadat di Minang sangatlah dekat atau berlandaskan pada agama, dan agama atau kepercayaannya berlandaskan kepada Al-Qur'an sebagai kitab Allah, secara singkat dimaknai bahwa adatnya tidak bertentangan dengan ajaran Islam.

Sebutan "Cina" atau "Tionghoa" bagi masyarakat Cina bukanlah sekedar soal sebutan, istilah, atau nama, tetapi menyangkut pelurusan sejarah yang telah dibelokkan pemerintah Orde Baru untuk melicinkan jalan guna mewujudkan kepentingan politiknya. Dilihat dari sejarahnya, gugatan terhadap sebutan "Cina" menjadi "Tionghoa" merupakan suatu protes atas peran negara dalam peniadaan hak suatu kelompok untuk mendefinisikan diri beserta identitasnya. Dikalangan orang Cina sendiri muncul keinginan kuat untuk mengganti istilah "Cina" dengan "Tionghoa", terutama setelah tumbangnya Soeharto dan Orde Baru (Yusuf, 2005). Berbeda dengan sebutan etnik Tionghoa, di Sumatera Barat khususnya di Padang, mayoritas orang menyebut etnik Tionghoa dengan sebutan "urang Cino" atau orang Cina. Berdasarkan pada pengamatan penulis, sebutan tersebut sudah lama terjadi bahkan dari awal etnik Tionghoa masuk ke ranah Minang. Orang yang dengan identitas kulitnya berwarna putih dan bermata sipit, lebih sering disebut orang Cino (Cina) di Sumatera Barat ketimbang orang Tionghoa. 


\section{Kesimpulan}

Kerukunan antar etnis Minang dan Tionghoa di kota Padang salah satunya terlihat dari akulturasi dan asimilasi dalam hubungan sosial budaya etnis tersebut. Kemampuan adabtasi etnis Tionghoa dan sistem matrilineal yang dianut oleh etnis Minang membuat potensi konflik dapat diredam. Di Padang, konflik atau kerusuhan antar suku nyaris tidak terjadi, salah satu sebabnya adalah di Minang memakai sistem matrilineal yang dikenal dengan Bundo Kanduang menekankan unsur motherhood dalam masyarakat Minang. Usaha etnik Tionghoa ini beradaptasi bahkan mau dipanggil orang Padang sangat terlihat dari bahasa sehari-hari yang mereka gunakan yaitu campuran antara bahasa Indonesia, bahasa Minang dan Mandarin atau dikenal dengan "bahasa Pondok" atau "bahasa Minang Pondok", seperti yang pernah disingung sebelumnya. Selain itu juga Adaptasi budaya berupa pakaian baju kurung, dan pelaksanaan adat istiadat yang sesuai dengan norma masyarakat setempat bahkan di "kampung Pondok" tempat domisili etnik Tionghoa ada beberapa kepala keluarga yang menganut agama Islam serta menjadikan Klenteng sebagai masjid tempat mereka beribadah.

\section{Daftar Pustaka}

1) Alfirdaus, L. K. 2014. Politik Relasi Etnik: Matrilinealitas dan Etnik Minoritas Cina di Padang, Sumatera Barat. Jurnal Komunitas.

2) Erniwati. 2007. Asap Hio di ranah Minang Komunitas Tionghoa di Sumatera. Yogyakarta: Ombak.

3) ------. 2011. Cina Padang Berbahasa Minang, Logat Mandarin. JPNN.com

4) Novalita, R. 2013. Dimensi Sosial Etnis Tionghoa yang Bermukim di Kota Bukittinggi. Lentera.

5) Rafni, A. 2007. Akses dan Kontrol Politik Perempuan Etnis Cina dalam Pemilu Legislatif 2004 di Kota Padang. Jurnal DEMOKRASI, Vol. VI No. 2.

6) Makmur, Riniwaty.2018. Etnik Tionghoa di Kota Padang Dima Bumi Dipijak, Di Situ Langik Dijunjuang (Studi Kasus Mengenai Komunikasi di Dalam Konstruksi Realitas Sosial pada Perkumpulan Etnik Tionghoa HImpunan Bersatu Teguh/HBT di Kota Padang). Disertasi. Bandung: Universitas Padjadjaran

7) Saputra, D. 2001. Marginalisasi Perempuan Cina (Tionghoa) di Indonesia. Jurnal Perempuan No.17.

8) Uhlin, A. (1997). Oposisi Berserak: Arus Deras Demokratisasi Gelombang Ketiga di Indonesia. Terjemahan Rofik Suhud. Bandung: Mizan.

9) Yusuf, I. A. (2005). Kematian, dan Identitas Budaya Minoritas (Representasi Etnik Tionghoa dalam Iklan Duka Cita). Yogyakarta: UII Press.

\section{Internet}

10) https://ikifuturity.wordpress.com 